
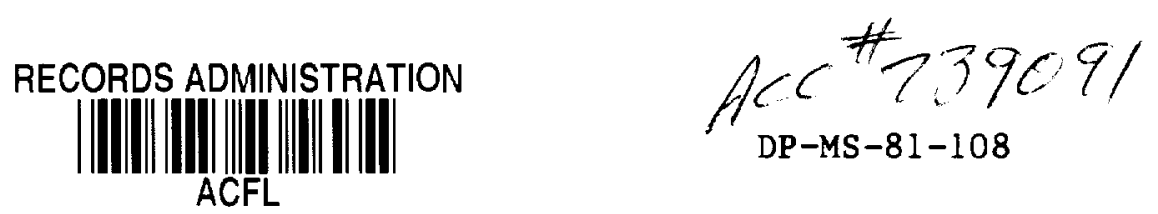

\title{
OPTIMIZATION OF GLASS COMPOSITION FOR THE VITRIFICATION OF NUCLEAR WASTE AT THE SAVANNAH RIVER PLANT
}

by

Pau 1 D. Soper, $\stackrel{*}{*}$ Gordon J. Roberts, $* * *$ Leo F. Lightner, $* * *$ Darrel D. Walker, $*$ and M. John Plodinec*

* E. I. du Pont de Nemours \& Company Savannah River Laboratory Aiken, South Carolina 29808

** Ferro Corporation/Technical Center 7500 East Pleasant Valley Road Independence, Ohio 44131

A paper proposed for presentation at the $84 \mathrm{th}$ Annual Meeting of the American Ceramic Society Cincinnati, Ohio

May 2-5, 1982

This paper was prepared in connection with work done under Contract No. DE-AC09-76SR00001 with the U.S. Department of Energy. By acceptance of this paper, the publisher and/or recipient acknowledges the U.S. Government's right to retain a nonexclusive, royalty-free license in and to any copyright covering this paper, along with the right to reproduce and to authorize others to reproduce all or part of the copyrighted paper. 
OPTIMIZATION OF GLASS COMPOSITION FOR THE VITRIFICATION OF NUCLEAR WASTE AT THE SAVANNAH RIVER PLANT

by

Paul D. Soper, * Gordon J. Roberts, $* *$ Leo F. Lightner, $* *$ Darrel D. Walker, $*$ and M. John Plodinec*

* E. I. du Pont de Nemours \& Company Savannah River Laboratory Aiken, South Carolina 29808

$* *$ Ferro Corporation/Technical Center 7500 East Pleasant Valley Road Independence, Ohio 44131

ABSTRACT

Waste glasses of different compositions were compared in terms of leachability, viscosity, liquidus temperature, and coefficient of expansion. The compositions of the glasses were determined by statistical optimization. Waste glass of the optimized composition is more durable than the current reference composition but can still be processed at low temperature.

The information contained in this article was developed during the course of work under Contract No. DE-AC09-76SR00001 with the U.S. Department of Energy. 


\section{INTRODUCTION}

In its 25 years of production of defense materials, the Savannah River Plant has generated about 25 million gallons of radioactive waste byproducts. This waste is currently stored in large underground tanks on the plant site. Processing of the waste into a form suitable for long-term disposal has been the subject of intense research efforts at the Savannah River Laboratory and elsewhere.

The waste consists of three fractions: an insoluble sludge, a salt cake, and a saturated supernatant solution. The sludge contains $95 \%$ of the total radioactivity of the waste, including virtually all of the actinides and long-lived radionuclides. The primary radionuclide in the salt and supernatant solution is Cs-137, on $1 y$ f $5 \%$ of which is found in the sludge. The sludge consists primarily of hydroxides and hydrous oxides of aluminum, iron, and manganese. These dictate the chemical and physical properties of the waste and play a major role in defining the limits of the solidification process.

Incorporation of the waste into borosilicate glass is the current reference process for immobilization. The properties of the resulting product glass are determined not only by the waste, but also by the glass-forming materials added during melting. This borosilicate glass frit is rough $1 \mathrm{y} 70 \%$ by weight of the final glass waste form. This frit must accommodate the entire range of waste compositions, which varies significantly (see Table 1). 
Current $1 \mathrm{y}$, melting temperatures are 1 imited to $1150^{\circ} \mathrm{C}$ by the volatility of radionuclides such as cesium and ruthenium, which means that the frit must be able to dissolve the waste at this temperature. The resulting waste glass must be highly resistant to aqueous attack.

An optimum frit was defined as one which produced waste glass with a leachability as low as possible, with a maximum viscosity at $1150^{\circ} \mathrm{C}$ as near 150 poise as possible, with a liquidus temperature as low as possible, and with a coefficient of thermal expansion as low as possible.

Such a frit composition was found after only 25 trials, in spite of the fact that eight chemical components were studied. This was achieved through application of the Nelder-Mead simplex algorithm, which uses the frits themselves to point toward the direction of improvement.

\section{Properties and Optimization Criteria}

Waste glasses made from each frit were compared in terms of their viscosities, coefficients of thermal expansion, leachabilities and liquidus temperatures. Since the glass frit must accommodate the entire range of waste compositions, each property was measured under "worst case" conditions -- high aluminum waste for viscosities and high iron for the other three properties. The waste compositions and concentrations are shown in Table 1 . The high-aluminum and high-iron waste simulations correspond to the 
highest concentrations of these two components in any SRP waste.

The TDS-3A and Stage 1 simulations represent average compositions.

The Stage 1 simulation is more recent and represents a somewhat

larger data base than was available when TDS-3A was developed.

The melting temperature, $1150^{\circ} \mathrm{C}$, and waste concentrations were

held fixed at the values specified for use with the current

reference frit, Frit 131 .

\section{- Viscosity}

High aluminum waste was used to prepare glasses for viscosity measurements since it produces melts of higher viscosity than other waste types. 1 An optimum viscosity at $1150^{\circ} \mathrm{C}$ of 150 poise was chosen. This represents a practical maximum for processing SRP waste. Increasing melt viscosity should reduce melter corrosion and volatility. Viscosities were measured using a Brookfield rotating spindle viscometer.

\section{- Liquidus}

High iron waste was used to prepare glasses for liquidus determinations since it is the most likely to form spinels during glass melting. 2 The liquidus temperature with high iron waste was to be minimized, to reduce the tendency to form slag in the melter. The liquidus was based on 24-hour tests in a gradient furnace. 


\section{- Leach Rate}

The leach rate used was the geometric mean of the leach rates at $\mathrm{pH}=4,7$, and 10 . It was to be minimized in the optimization. All leach tests were performed at $90^{\circ} \mathrm{C}$ on $-40+60$ mesh grains of simulated waste glass, which has a specific surface area of $0.007 \mathrm{~m}^{2} / \mathrm{g}$. For the first twelve frits, TDS-3A simulated waste was used and the tests were based on $2 \mathrm{~g}$ of glass in $20 \mathrm{~mL}$ of $\mathrm{pH}=3,7$, and 11 buffer for three days. Leach rates were calculated from the concentration of silicon in the leaching solutions as measured by inductively coupled plasma emission spectroscopy and on the calculated fraction of silicon in the simulated waste glass. Since the only function of this test is to compare different glasses, a more sophisticated test is not justified. Several changes were made in the leach tests used after the first round to improve the ability of the test to accurately discriminate between the waste glass compositions tested. To minimize possible saturation of the leach solution, the mass of glass was halved (to $1 \mathrm{~g}$ ), the volume of solution was increased (to $40 \mathrm{~mL}$ ), and the test was shortened to 24 hours. In the first round, the laboratory buffers used were not always able to buffer the leach solutions, so they were replaced by commercial $\mathrm{pH} 4,7$, and 10 buffers. Finally, high iron waste was used in place of TDS-3A simulated waste, since this produced glass of lower durability. 2 Because of variations in leach test results, all of the waste 
glasses to be compared in a given round were tested together, even if earlier data were available.

\section{Coefficient of Thermal Expansion}

This property, measured on high iron waste glass, was to be minimized. Since the strength of the glass is inversely proportional to this coefficient, cracking may be reduced as the coefficient is lowered. The coefficient of thermal expansion was measured on an Orton dilatometer. The values reported are those for the range 25 to $300^{\circ} \mathrm{C}$.

These four properties were combined into a quality index for the different compositions. Each property was projected on a common scale, and weighted in proportion to its importance. The common scale ran from 0 (intolerable) to 1 (optimum). The relationship of this scale to the measured properties is shown in Slide 1. Except for the viscosity, each scale runs in a linear fashion from the intolerable to the optimum value. The viscosity is treated differently in order to reduce the penalty for small deviations from the optimum value of 150 poise. The following relationship between the viscosity $n$ and its desirability coefficient $C_{n}$ was used:

$$
C_{n}=\left(1-\frac{|\eta-150|}{150}\right)^{\frac{1}{2}}
$$

Futhermore, $\mathrm{C}_{n}$ was not allowed to drop below 0.258 , its value at 10 or 290 poise. If the value of $C_{\eta}$ had been allowed to go 
to zero, this value would have unduly affected the resultant statistical optimization. In practice this made little difference, since a $C_{\eta}$ value of 0.258 was enough to eliminate the frit from consideration as the best possible one.

The common scale eliminated the problem of "comparing apples and oranges," e.g., a value of 0.8 on the scale corresponds to a viscosity of 96 or 204 poise, a liquidus temperature of $700^{\circ} \mathrm{C}$, a coefficient of thermal expansion of

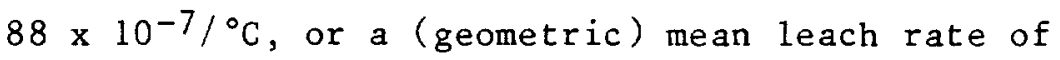
$0.100 \mathrm{~g} / \mathrm{m}^{2}-\mathrm{day}$.

These properties are not all of equal importance. The durability is most important with a relative ranking of $40 \%$. Viscosity is next with $30 \%$, then liquidus temperature at $20 \%$, and finally the coefficient of thermal expansion at $10 \%$. Since the overall coefficient of desirability is the geometric mean of the desirability coefficients for the individual properties, these weighting factors appear as exponents -- 1.6 for durability, 1.2 for viscosity, 0.8 for liquidus, and 0.4 for the coefficient of thermal expansion. These exponents are readily calculated from the weights and the requirement that they sum to the number of properties, 4. Slide 2 shows how these exponents shift the desirability coefficients. A desirability coefficient of 0.8 on the common scale corresponds to a weighted coefficient of 0.70 for the durability, 0.77 for the viscosity, 0.84 for the liquidus, and 0.91 for the coefficient 
of thermal expansion. This is just as one would expect: the weighted coefficient for the durability has a greater ability to reduce the frit's overall desirability coefficient than does that for the coefficient of thermal expansion.

Once the desirability coefficient of each waste glass was calculated, the frits were ranked from best (geometric mean of weighted desirability coefficients closest to 1) to worst. The rankings and properties of the waste glasses included in the first, second and third rounds are listed in Tables 2, 3 and 4, respectively.

The rankings in each round were used to generate the compositions to be studied in the next round as described below.

\section{Compositions}

The compositions of all frits studied in this program are shown in Table 5. The first twelve compositions were determined by a Plackett-Burman design. ${ }^{3}$ Each of the eight components was assigned a "high" value and a "low" value, e.g., 70 and 60 parts by weight for silica. The compositions were normalized to 100 wt \%.

Data were collected on waste glasses made from the first twelve frits and the frits were then ranked as described above. The four worst compositions were replaced. It is this focusing on the worst cases which is the strength of this approach. The optimum frit is hard to identify because its exact properties are unknown. There is certainly no reason to assume that it is one of 
the compositions initially studied. On the other hand, the less desirable frits are quite easy to pick out -- here one need not worry about whether it is the worst possible frit, but simply whether it is poor.

These four frits are used to generate the next set of trial frits through a simplex algorithm. This algorithm was first developed by Spendley et $a 1^{4}$ and later extended by Nelder and Mead. 5 A lucid but somewhat less technical exposition is also available. 6 The composition of each poor frit is subtracted from twice the average of the eight better frits. This is a reflection of the poor composition through the point of average composition in composition space. There is no absolute guarantee that the new composition will be better (i.e., have a higher desirability coefficient) than the one it replaces. It may overshoot the optimum region altogether. However, as long as there is any progress the optimum region will eventually be approached. Slide 3 shows a two-dimensional respresentation of this reflection for the twelve frits initially studied. Referring to Tables 2 and 5, Frit 141 was replaced by Frit 154, Frit 142 by Frit 155 , Frit 148 by Frit 156 , and Frit 149 by Frit 157 . These twelve frits -- eight older ones and four new ones -- were studied as a group and analyzed in exactly the same way as was the first group. This led to replacing Frits 144, 146, 155, and 157 by Frits $158,159,160$, and 161 respectively. This evolution can be followed by examining Tables 2 through 4 , where the data on the 
simulated waste glasses made from each frit appears as well as the desirability coefficients used to determine the ranking.

While the statistics work by examining the worst frits, the end result is reached by examining the best. The statistically directed part of this experiment was concluded once it became clear that the region of best composition was not changing significantly. This occurred after the third round. By this time twenty frits had been studied.

The data representing these frits served as the basis for the final step, the proposal of an "optimum" frit. Two different approaches were used to generate this composition. One was to use knowledge attained in general glass manufacture along with experience with the first twenty frits to produce the compositions of Frit 162, 163, and 166. The other approach was an attempt to fit the observed properties to linear combinations of the components. This was reasonably successful in the cases of the two most important properties, the (geometric) mean leach rate and the viscosity. Although a linear fit of the liquidus temperature failed every statistical test for significance, it did suggest that lanthana was the only component to dramatically increase (i.e., worsen) that temperature. Because of its low weighting, the coefficient of thermal expansion was not modeled. The results were applied in developing the compositions of Frits 164 and 165. Both of these approaches reached similar conclusions as regards the effects of most of the components. In general, higher 
amounts of silica and zirconia improve durability. The higher viscosity is best compensated for by increasing lithia relative to soda since it is a more effective flux (on a weight percent basis) and has a less deleterious effect on the leach rate. Lanthana has no benefits to recommend its inclusion. Boric oxide, magnesia, and titania have a relatively smaller impact on the measured properties.

The properties of these final five frits are compared to that of Frit 154, the best frit generated by the simplex algorithm, in Table 6. Three of the five -- Frits 164, 165, and 166 -- were significantly better than Frit 154. These three were so similar in desirability coefficient and in their individual properties that an additional test to choose between them was needed. The test used was a simple side-by-side comparison of their resistance to devitrification.

Frit 131 (the current reference frit) and Frits 154, 164, 165 and 166 were used to prepare waste glasses using "Stage 1" simulated waste calcine (see Table 1). After being held at $1150^{\circ} \mathrm{C}$ for eight hours, they were cooled in a programmed furnace in such a way as to mimic the behavior in the center of an uninsulated stainless steel canister of the kind proposed for nuclear waste glass. ${ }^{7}$ Glass in this location sees the slowest cooling rate and spends the longest time between the liquidus and the glass transition temperatures. It represents the worst case for crystal formation. The results of this experiment were striking; Frit 131 
waste glass contained the most crystalline material, followed by Frits 166, 154, 164 and 165. In Frit 165, only a few smal1 wel1-separated cyrstals could be found. As a result of this test, Frit 165 was chosen for further study.

\section{SUMMARY}

The compositions and properties of the reference frit, Frit 131 , and the best frit of the optimization program, Frit 165, are compared in Tables 7 and 8 . Frit 165 waste glass is superior to Frit 131 waste glass with respect to every property measured. It is more resistant to leaching, especially in acid solution; it is more viscous, reducing corrosion of electrodes and refractory materials in the melter; it is less likely to devitrify under adverse cooling conditions; and it has a lower coefficient of thermal expansion, which may reduce the severity of cracking during cooling.

The development of Frit 165 required only 25 test frits, demonstrating the power of the simplex approach even in as complicated a problem as this one.

The properties included in this study are not the only ones of interest in processing nuclear waste glass. The inclusion of all such properties would have made the experiment intractable. Future work on Frit 165 will shift from crucible tests of the sort described here to ful1-scale studies which will measure its performance in each phase of melter operation -- feeding, melting, 
and pouring -- as well as examine the quality of the glass

produced in longer-term tests. It is anticipated that Frit 165

will continue to show both processing and product quality

improvements over earlier frits.

\section{ACKNOWLEDGMENTS}

The authors would like to thank B. J. Waters of the Savannah River Laboratory and J. Matthews of Ferro Corporation for their efforts in collecting the experimental data reported above, and Dr. C. J. Coleman of the Savannah River Laboratory for his spectrographic analys is of the leachants. 


\section{REFERENCES}

1. M. J. Plodinec. Viscosity of Glasses Containing Simulated Savannah River Plant Waste. USDOE Report DP-1507, (1978). E. I. du Pont de Nemours \& Co., Aiken, South Carolina (1978).

2. B. M. Robnett and G. G. Wicks. Effect of Devitrification on the Leachability of High-Level Radioactive Waste Glass. submitted to Nuclear Technology.

3. R. L. Plackett and J. G. Burman. The Design of Optimum Multifactional Experiments. Biometrika, 33305 (1946).

4. W. Spendley, G. R. Hext, and F. R. Himsworth. Sequential Application of Simplex Designs in Optimization and Evolutionary Operation. Technometrics, 4, 441 (1962).

5. J. A Nelder and R. Mead. A Simplex Method for Function Minimization. Computer Journal, 7, 308 (1965).

6. C. Hendrix. Through the Response Surface with Test Tube and Pipe Wrench. Chemtech, p. 448, (1980).

7. M. J. Plodinec, G. G. Wicks and N. E. Bibler. An Assessment of Savannah River Borosilicate Glass in the Repository Environment. USDOE Report DP-1629, E. I. du Pont de Nemours \& Co., Savannah River Laboratory, Aiken, South Carolina (1982). 
TABLE 1

Simulated Calcine Compositions

\begin{tabular}{|c|c|c|c|c|}
\hline \multirow{2}{*}{ Component } & \multicolumn{4}{|c|}{ Amount (Wt \%) } \\
\hline & $\overline{\mathrm{W}-\mathrm{A} 1}$ & $\mathrm{~W}-\mathrm{Fe}$ & Stage 1 & TDS-3A \\
\hline $\mathrm{Fe}_{2} \mathrm{O}_{3}$ & 13.8 & 59.1 & 41.3 & 47.3 \\
\hline $\mathrm{MnO}_{2}$ & 11.3 & 4.0 & 11.5 & 13.6 \\
\hline Zeolite* & 10.2 & 9.7 & 6.7 & 10.2 \\
\hline $\mathrm{A}_{2} \mathrm{O}_{3}$ & 49.3 & 1.4 & 15.2 & 9.5 \\
\hline NiO & 2.0 & 10.1 & 3.5 & 5.8 \\
\hline $\mathrm{SiO}_{2}$ & 4.5 & 2.9 & 10.6 & 4.1 \\
\hline $\mathrm{CaO}$ & 0.9 & 4.0 & 4.9 & 3.5 \\
\hline $\mathrm{Na}_{2} \mathrm{O}$ & 5.0 & 5.9 & -- & 3.1 \\
\hline Coa 1 & 2.3 & 2.1 & 1.0 & 2.3 \\
\hline $\mathrm{Na}_{2} \mathrm{SO}_{4}$ & 0.7 & 0.8 & 0.4 & 0.6 \\
\hline $\mathrm{Na}_{2} \mathrm{CO}_{3}$ & -- & -- & 4.9 & -- \\
\hline $\begin{array}{l}\text { Frit/Calcine } \\
\text { Ratio }\end{array}$ & $71.3 / 28.7$ & $70.2 / 29.8$ & $69.4 / 30.6$ & $70.2 / 29.8$ \\
\hline
\end{tabular}


TABLE 2

Results of the First Round in Order of Decreasing Desirability Coefficient

Leach Rates, $*\left(\mathrm{~g} / \mathrm{m}^{2}-\mathrm{day}\right)$

$\begin{array}{lll}\text { Liquidus } \dagger & \text { Coefficient } \dagger \text { Weighted } \\ \text { Geometric Viscosity** Temp., } & \text { of Expansion, Desirability }\end{array}$

\begin{tabular}{|c|c|c|c|c|c|c|c|c|}
\hline Frit & $\mathrm{pH} 3$ & $\mathrm{pH} 7$ & $\mathrm{pH} 11$ & Mean & (Poise) & ${ }^{\circ} \mathrm{C}$ & $10^{-7 /} /{ }^{\circ} \mathrm{C}$ & Coefficient \\
\hline 147 & 0.069 & 0.034 & 0.84 & 0.125 & 164 & 804 & 97.5 & 0.746 \\
\hline 143 & 0.074 & 0.036 & 1.30 & 0.151 & 174 & 835 & 100.4 & 0.692 \\
\hline 145 & 0.052 & 0.063 & 2.00 & 0.187 & 137 & 820 & 108.4 & 0.643 \\
\hline 152 & 0.093 & 0.055 & 1.70 & 0.206 & 123 & 840 & 102.5 & 0.634 \\
\hline 151 & 0.091 & 0.055 & 1.90 & 0.212 & 98 & 860 & 100.4 & 0.605 \\
\hline 146 & 0.084 & 0.032 & 1.40 & 0.156 & 100 & 927 & 104.0 & 0.598 \\
\hline 150 & 0.095 & 0.070 & 1.70 & 0.224 & 102 & 790 & 109.1 & 0.593 \\
\hline 144 & 0.100 & 0.093 & 1.10 & 0.217 & 82 & 784 & 109.8 & 0.579 \\
\hline 148 & 0.100 & 0.069 & 1.00 & 0.190 & 98 & 937 & 99.6 & 0.579 \\
\hline 149 & 0.046 & 0.009 & 0.91 & 0.072 & 313 & 848 & 88.7 & 0.532 \\
\hline 142 & 0.051 & 0.011 & 0.61 & 0.070 & 334 & 870 & 88.0 & 0.525 \\
\hline 141 & 0.130 & 0.096 & 1.90 & 0.287 & 94 & 862 & 106.2 & 0.513 \\
\hline
\end{tabular}

* Based on 3 -day tests at $90^{\circ} \mathrm{C}$ of glass powder prepared using TDS-3A waste.

$\star *$ With high aluminum waste.

$\dagger \dagger$ with high iron waste. 
TABLE 3

Results of the Second Round in Order of Decreasing Desirability Coefficient

Leach Rates, * $g / m^{2}-d a y$

\begin{tabular}{|c|c|c|c|c|c|c|c|c|}
\hline Frit & $\mathrm{pH} 4$ & $\underline{\mathrm{pH}} 7$ & $\mathrm{pH} \quad 10$ & $\begin{array}{l}\text { Geometric } \\
\text { Mean }\end{array}$ & $\begin{array}{l}\text { Viscosity } * * \\
\text { (Poise) } \\
\end{array}$ & $\begin{array}{l}\text { Liquidus } \\
\text { Temp. }, \dagger \\
{ }^{\circ} \mathrm{C} \\
\end{array}$ & $\begin{array}{l}\text { Coefficient } \\
\text { of Expansion, } \dagger \\
10^{-7} /{ }^{\circ} \mathrm{C} \\
\end{array}$ & $\begin{array}{l}\text { Weighted } \\
\text { Desirability } \\
\text { Coefficient } \\
\end{array}$ \\
\hline 154 & 0.207 & 0.112 & 0.437 & 0.216 & 176 & 850 & 98.2 & 0.635 \\
\hline 147 & 0.455 & 0.084 & 0.466 & 0.261 & 164 & 804 & 97.5 & 0.623 \\
\hline 143 & 0.248 & 0.110 & 0.477 & 0.235 & 174 & 835 & 100.4 & 0.620 \\
\hline 156 & 0.441 & 0.084 & 0.406 & 0.247 & 177 & 840 & 99.6 & 0.606 \\
\hline 145 & 0.346 & 0.110 & 0.468 & 0.261 & 137 & 820 & 108.4 & 0.578 \\
\hline 152 & 0.597 & 0.088 & 0.388 & 0.273 & 123 & 840 & 102.5 & 0.572 \\
\hline 151 & 0.337 & 0.115 & 0.469 & 0.263 & 98 & 860 & 100.4 & \\
\hline 150 & 0.581 & 0.083 & 0.419 & 0.272 & 102 & 790 & 109.1 & \\
\hline 146 & 0.438 & 0.096 & 0.432 & 0.263 & 100 & 927 & 104.0 & \\
\hline 144 & 0.639 & 0.098 & 0.431 & 0.300 & 82 & 784 & 109.8 & \\
\hline 157 & 0.611 & 0.116 & 0.487 & 0.326 & 61 & 805 & 112.7 & \\
\hline 155 & 0.605 & 0.159 & 0.461 & 0.354 & 80 & 800 & 111.3 & \\
\hline
\end{tabular}

* Based on 1-day tests at $90^{\circ} \mathrm{C}$ on powder, with high iron waste.

$* *$ With high iron waste.

$\dagger$ With high aluminum waste. 
TABLE 4

Results of the Third Round in Order of Decreasing Desirability Coefficient

\begin{tabular}{|c|c|c|c|c|c|c|c|c|}
\hline Frit & $\mathrm{pH} 4$ & $\underline{\mathrm{pH}} 7$ & $\mathrm{pH} \quad 10$ & $\begin{array}{l}\text { Geometric } \\
\text { Mean } \\
\end{array}$ & $\begin{array}{l}\text { Viscosity, } \\
\text { (Poise) } \\
\end{array}$ & $\begin{array}{l}\text { Liquidus } \dagger \\
\text { Temp., } \\
{ }^{\circ} \mathrm{C} \\
\end{array}$ & $\begin{array}{l}\text { Coefficient } \\
\text { of expansion, } \dagger \\
10^{-7} /{ }^{\circ} \mathrm{C} \\
\end{array}$ & $\begin{array}{l}\text { Weighted } \\
\text { Desirability } \\
\text { Coefficient } \\
\end{array}$ \\
\hline 154 & 0.171 & 0.088 & 0.451 & 0.189 & 176 & 850 & 98.2 & 0.658 \\
\hline 147 & 0.560 & 0.067 & 0.428 & 0.252 & 164 & 804 & 97.5 & 0.633 \\
\hline 151 & 0.324 & 0.096 & 0.491 & 0.248 & 98 & 860 & 100.4 & 0.573 \\
\hline 152 & 0.471 & 0.108 & 0.426 & 0.279 & 123 & 840 & 102.5 & 0.566 \\
\hline 160 & 0.357 & 0.210 & 0.427 & 0.318 & 158 & 840 & 96.7 & 0.551 \\
\hline 156 & 0.521 & 0.119 & 0.461 & 0.306 & 177 & 840 & 99.6 & 0.545 \\
\hline 150 & 0.576 & 0.088 & 0.426 & 0.278 & 102 & 790 & 109.1 & 0.544 \\
\hline 145 & 0.601 & 0.101 & 0.479 & 0.307 & 137 & 820 & 108.4 & 0.530 \\
\hline 143 & 0.437 & 0.183 & 0.610 & 0.365 & 174 & 835 & 100.4 & 0.473 \\
\hline 161 & 0.095 & 0.253 & 0.521 & 0.232 & 1200 & 890 & 88.0 & 0.427 \\
\hline 159 & 0.163 & 0.282 & 0.525 & 0.289 & 376 & 953 & 92.4 & 0.356 \\
\hline 158 & 0.296 & 0.288 & 0.422 & 0.330 & 377 & 900 & 85.8 & 0.354 \\
\hline
\end{tabular}

\footnotetext{
* Based on 1-day tests at $90^{\circ} \mathrm{C}$ on powder.

$* *$ With high iron waste.

$\dagger \dagger$ With high aluminum waste.
} 
TABLE 5

\section{Composition of Frits}

Weight Percent

\begin{tabular}{|c|c|c|c|c|c|c|c|c|}
\hline Frit & $\mathrm{SiO}_{2}$ & $\mathrm{~B}_{2} \mathrm{O}_{3}$ & $\mathrm{Na}_{2} \mathrm{O}$ & $\mathrm{Li}_{2} \mathrm{O}$ & $\mathrm{MgO}$ & $\frac{\mathrm{TiO}_{2}}{2}$ & $\mathrm{La}_{2} \mathrm{O}_{3}$ & $\mathrm{ZrO}_{2}$ \\
\hline 41 & 58.8 & 14.7 & 17.6 & 3.9 & 2.0 & 2.0 & 1.0 & 0.0 \\
\hline 142 & 66.0 & 14.2 & 12.3 & 3.8 & 0.9 & 1.9 & 0.0 & 0.9 \\
\hline 143 & 64.8 & 13.9 & 12.0 & 5.6 & 1.9 & 1.9 & 0.0 & 0.0 \\
\hline 144 & 59.4 & 14.9 & 17.8 & 5.9 & 1.0 & 0.0 & 0.0 & 1.0 \\
\hline 145 & 64.8 & 11.1 & 16.7 & 5.6 & 1.9 & 0.0 & 0.0 & 0.0 \\
\hline 146 & 63.1 & 10.8 & 16.2 & 5.4 & 0.9 & 1.8 & 0.9 & 0.9 \\
\hline 147 & 66.7 & 13.3 & 14.4 & 4.4 & 1.1 & 0.0 & 0.0 & 0.0 \\
\hline 148 & 61.2 & 15.3 & 13.3 & 6.1 & 2.0 & 0.0 & 1.0 & 1.0 \\
\hline 149 & 68.0 & 11.7 & 12.6 & 3.9 & 1.9 & 0.0 & 1.0 & 1.0 \\
\hline 150 & 60.6 & 12.1 & 18.2 & 4.0 & 2.0 & 2.0 & 0.0 & 1.0 \\
\hline 151 & 63.2 & 12.6 & 13.7 & 6.3 & 1.1 & 2.1 & 1.1 & 0.0 \\
\hline 152 & 64.2 & 13.8 & 16.5 & 3.7 & 0.9 & 0.0 & 0.9 & 0.0 \\
\hline 154 & 67.6 & 10.9 & 13.8 & 6.3 & 0.7 & 0.0 & 0.0 & 0.7 \\
\hline 155 & 60.3 & 11.3 & 19.3 & 6.5 & 1.8 & 0.0 & 0.8 & 0.0 \\
\hline 156 & 65.0 & 10.4 & 17.9 & 4.2 & 0.7 & 1.9 & 0.0 & 0.0 \\
\hline 157 & 58.4 & 13.9 & 18.7 & 6.3 & 0.7 & 1.9 & 0.0 & 0.0 \\
\hline 158 & 68.5 & 13.1 & 11.7 & 3.5 & 0.8 & 1.9 & 0.0 & 0.4 \\
\hline 159 & 69.3 & 9.7 & 13.0 & 4.1 & 1.6 & 1.9 & 0.5 & 0.0 \\
\hline 160 & 65.7 & 13.8 & 14.3 & 4.5 & 1.7 & 0.0 & 0.0 & 0.0 \\
\hline 161 & 70.9 & 10.6 & 12.1 & 3.7 & 1.8 & 0.0 & 0.5 & 0.4 \\
\hline 162 & 67.5 & 13.0 & 13.0 & 4.0 & 1.0 & 1.0 & 0.0 & 0.5 \\
\hline 163 & 68.0 & 13.0 & 12.0 & 4.5 & 1.0 & 1.0 & 0.0 & 0.5 \\
\hline 164 & 67.0 & 10.0 & 13.0 & 7.0 & 1.0 & 0.0 & 0.0 & 2.0 \\
\hline 165 & 68.0 & 10.0 & 13.0 & 7.0 & 1.0 & 0.0 & 0.0 & 1.0 \\
\hline 166 & 67.0 & 12.0 & 14.0 & 5.5 & 1.0 & 0.0 & 0.0 & 0.5 \\
\hline
\end{tabular}


TABLE 6

Results of the Final Round in Order of Decreasing Desirability Coefficient

\begin{tabular}{|c|c|c|c|c|c|c|c|}
\hline Frit & $\mathrm{pH} 4$ & $\mathrm{pH} 7$ & $\underline{\mathrm{pH} \quad 10}$ & $\begin{array}{l}\text { Geometric } \\
\text { Mean }\end{array}$ & $\begin{array}{l}\text { Viscosity** } \\
\text { poise }\end{array}$ & $\begin{array}{l}\text { Liquidus } \\
\text { Temp, }+* * * \\
{ }^{\circ} \mathrm{C} \\
\end{array}$ & $\begin{array}{l}\text { Coefficient } \\
\text { of Expansion, } \frac{1}{6}+\cdots \\
10^{-7} /{ }^{\circ} \mathrm{C} \\
\end{array}$ \\
\hline 166 & 0.215 & 0.119 & 0.461 & 0.228 & 159 & 855 & 97.4 \\
\hline 164 & 0.135 & 0.174 & 0.434 & 0.217 & 130 & 855 & 99.6 \\
\hline 165 & 0.165 & 0.125 & 0.477 & 0.214 & $140 \dagger \dagger$ & 875 & 100.4 \\
\hline $154+$ & 0.278 & 0.151 & 0.491 & 0.274 & 176 & 850 & 98.2 \\
\hline 163 & 0.247 & 0.145 & 0.497 & 0.261 & 229 & 865 & 88.7 \\
\hline 162 & 0.287 & 0.138 & 0.543 & 0.278 & 382 & 845 & 90.2 \\
\hline $131 \dagger$ & 0.586 & 0.161 & 0.458 & 0.351 & 84 & 957 & 110.5 \\
\hline
\end{tabular}

Weighted Desirabilit Coefficient

0.636

0.632

0.628

0.579

0.558

\footnotetext{
* Based on 1 -day tests at $90^{\circ} \mathrm{C}$ on powder, with high iron waste.

t* With high aluminum waste.

int With high iron waste.

$\dagger$ Included for reference.

$\dagger \dagger$ Estimated.
} 
TABLE 7

Compositions of Frits 131 and 165

Weight Percent

Component

Frit 131 Frit 165

$\begin{array}{lcr}\mathrm{SiO}_{2} & 57.9 & 68.0 \\ \mathrm{~B}_{2} \mathrm{O}_{3} & 14.7 & 10.0 \\ \mathrm{Na}_{2} \mathrm{O} & 17.7 & 13.0 \\ \mathrm{Li}_{2} \mathrm{O} & 5.7 & 7.0 \\ \mathrm{MgO} & 2.0 & 1.0 \\ \mathrm{TiO}_{2} & 1.0 & -- \\ \mathrm{La}_{2} \mathrm{O}_{3} & 0.5 & -- \\ \mathrm{ZrO}_{2} & 0.5 & 1.0\end{array}$


TABLE 8

Properties of Waste Glasses Made from Frits 131 and 165

Property

Leach Rates

$\mathrm{g} / \mathrm{m}^{2}$-day

$\mathrm{pH} 4$

$\mathrm{pH} 7$

$\mathrm{pH} 10$

Geometric Mean

Viscosity, Poise

(at $1150^{\circ}$ )

Liquidus Temp., ${ }^{\circ} \mathrm{C}$

Coefficient of

Expansion

$10^{-7} /{ }^{\circ} \mathrm{C}$

$\mathrm{Tg},{ }^{\circ} \mathrm{C}$

Dilatometric

Softening

Point, ${ }^{\circ} \mathrm{C}$
Waste Glass

Frit 131

0.586

0.161

0.458

0.351

84.0

140.0

957.0

875.0

110.5

100.4

445.0

449.0

490.0

484.0 
COMMON SCALE
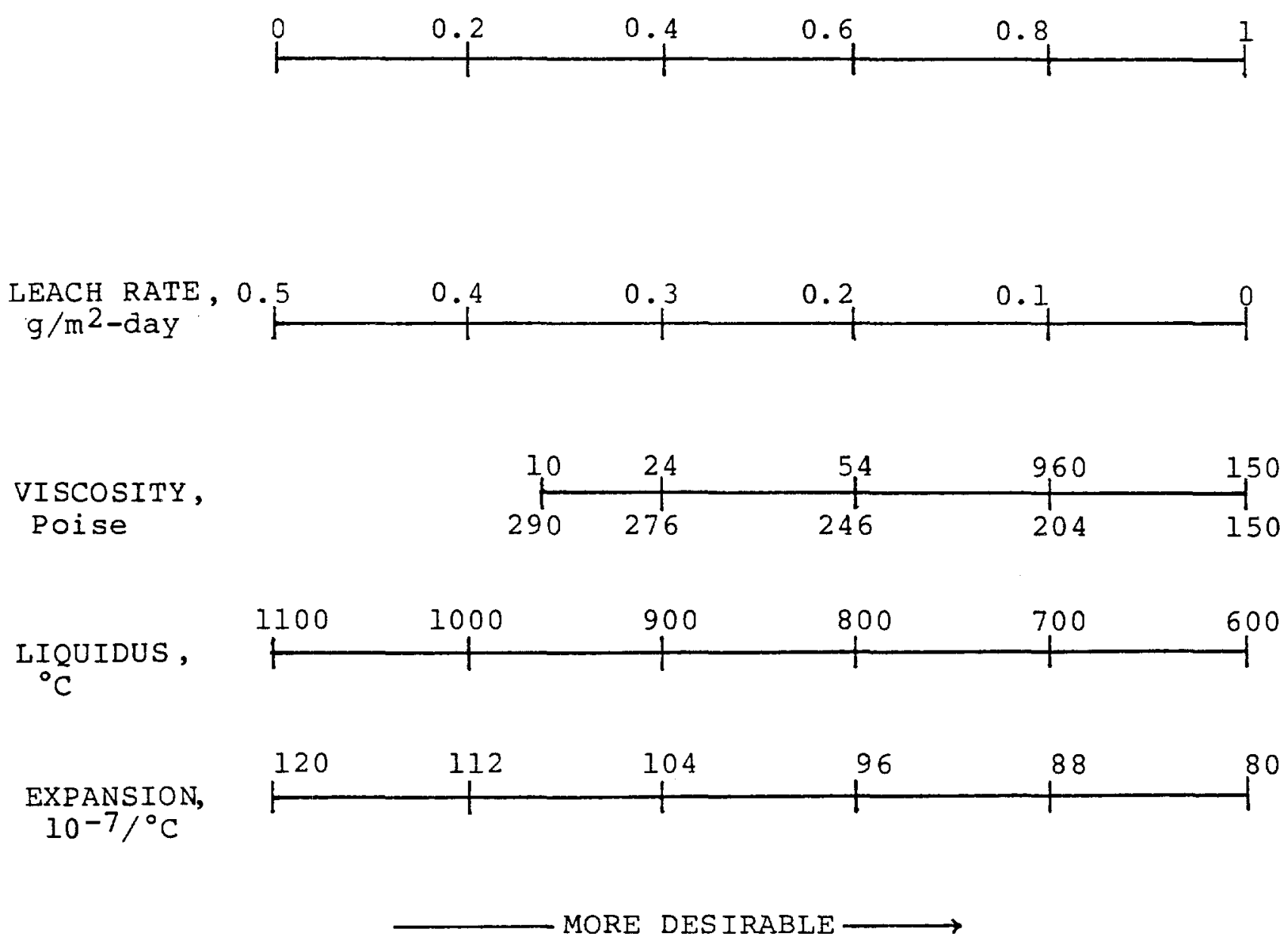

SLIDE 1. Relationship Between the Measured Properties and the Common Scale. A Common Scale Value of 0 is Intolerable while a Values of 1 is ideal. 


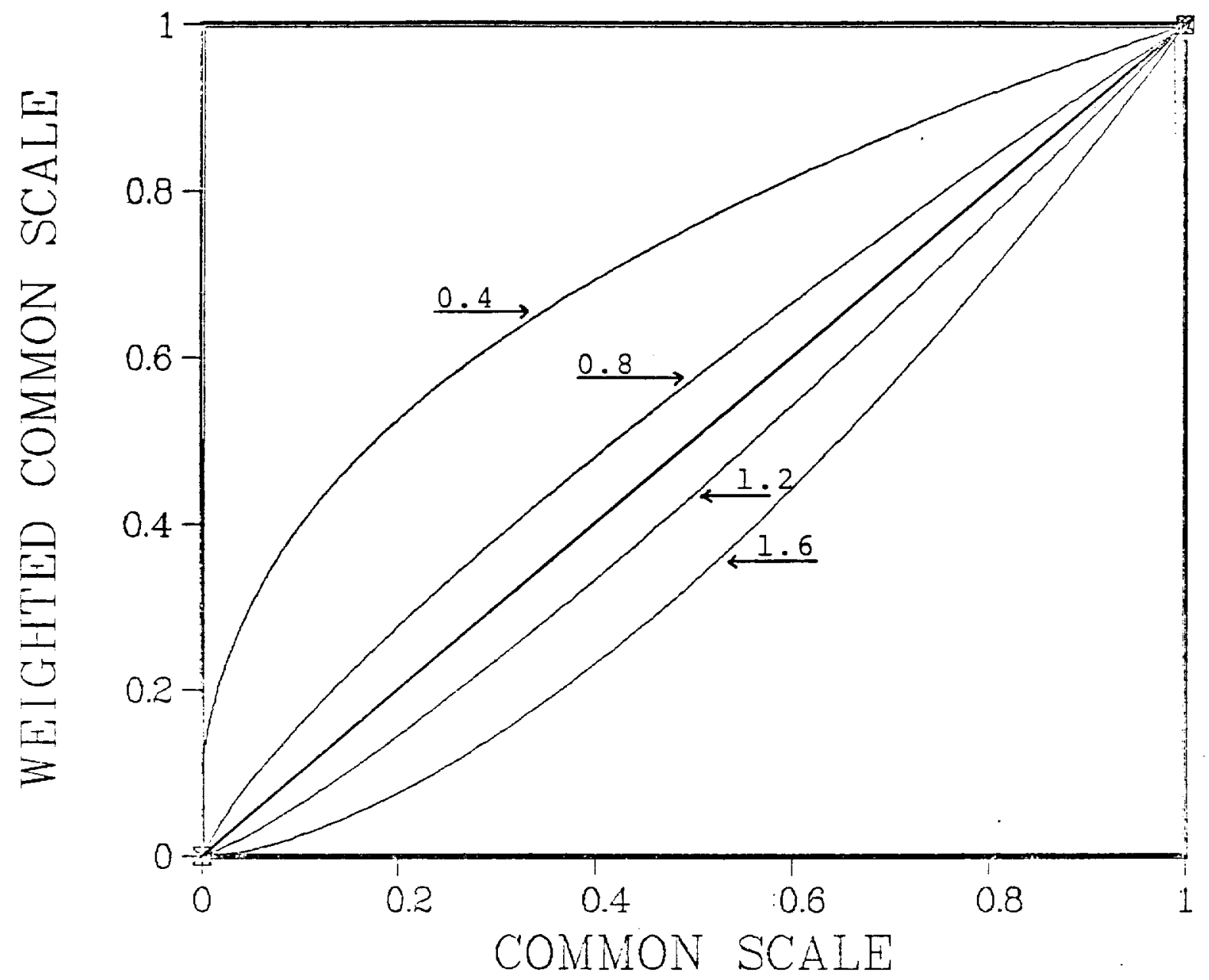

SLIDE 2. Relationship Between the Common Scale and the Weighted Common Scale. The Mean Leach Rate Weighting Factor is 1.6 , the Viscosity Factor is 1.2 , the Liquidus Factor is 0.8 , and the Expansion Factor is 0.4 . 


\section{FRIT COMPOSITIONS}

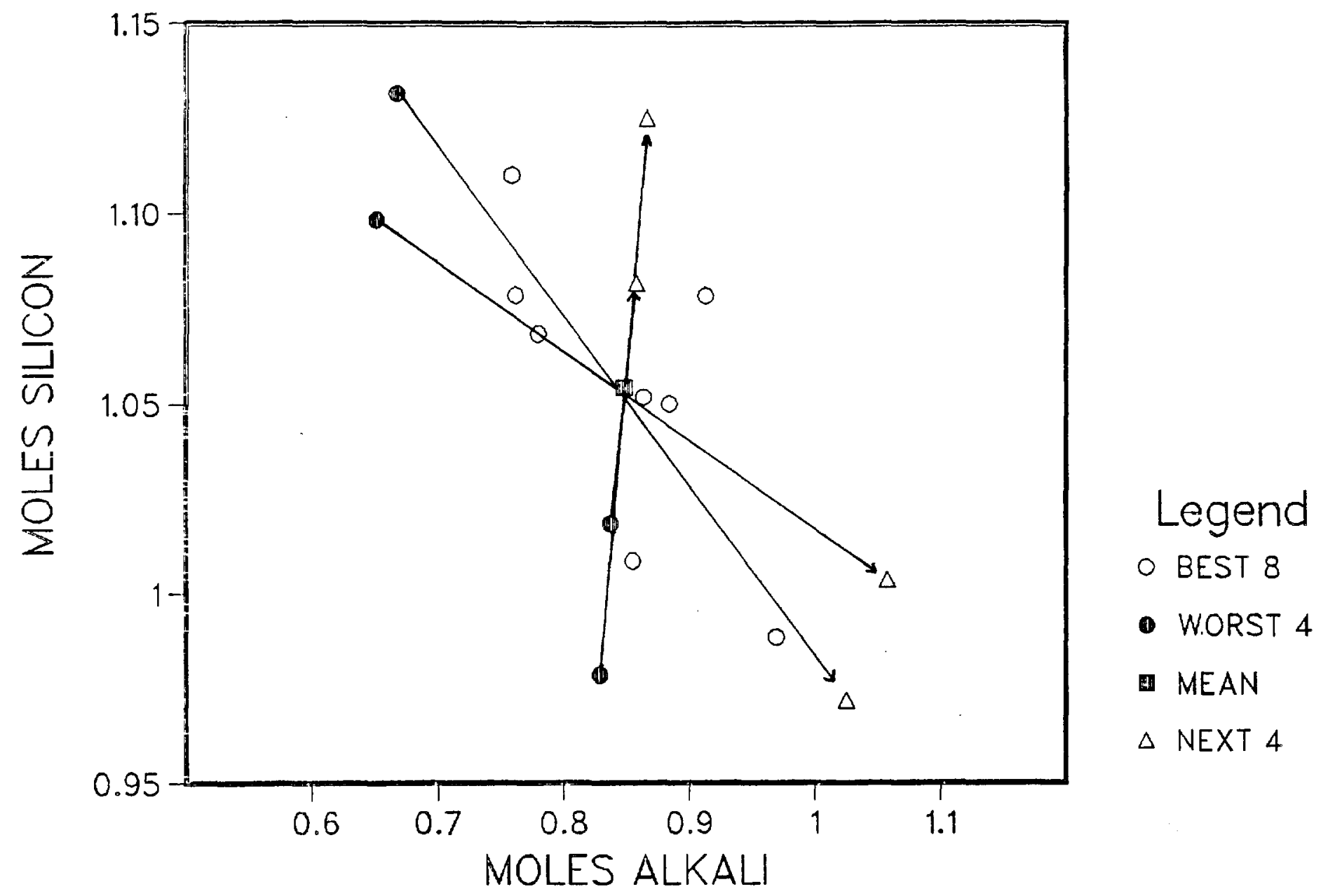

SLIDE 3. Composition Generation by the Nelder-Mead Simplex Algorithm. The Data on Waste Glasses Made with the Twelve Frits are Used to Rank Them. They are Split into the Best $8(0)$ and the Worst $4(0)$. The Average Composition of the Best 8 is Calculated (G). Each of the Worst 4 Compositions is Reflected Through the Average to Give a New Composition $(\Delta)$. 